УАK 34 (091)

ББК 67.3

DOI 10.22394/1682-2358-2021-2-80-87

E.V. Zazolina, post-graduate student of the Legal Theory Department, Dubna State University, Head of territorial department No. 27 of Rosreestr Branch in Moscow region

\section{LEGAL REGULATION OF LAND SURVEYING IN THE RUSSIAN EMPIRE: HISTORICAL AND LEGAL ASPECT}

The legal basis for the procedure of land surveying is considered. The main stages of the land surveying institute formation in the aspect of the Russian statehood formation and development are analyzed. The historical and legal analysis of the reform of the General Land Surveying of 1765 is drawn. The author made proposals to improve the current legislation in the field of complex cadastral works.

Key words and word-combinations: general land survey, land use, Russian Empire.
E.В. Зазолина, аспирант кафедро теории права Государственного университета «Аубна», начальник территориального отдела № 27 Филиала Росреестра по Московской области (етаil: elena_zazolina@mail.ru)

\section{ПРАВОВОЕ РЕГУ ИИРОВАНИЕ МЕЖЕВАНИЯ ЗЕМЕ В РОССИЙСКОЙ ИМПЕРИИ: ИСТОРИКО-ПРАВОВОЙ АCПEКT}

Аннотация. Рассматриваются правовые основы проведения процедуры межевания земель. Анализируются основные этапы формирования института межевания в аспекте становления и развития российской государственности. Проводится историко-правовой анализ реформы Генерального межевания земель 1765 г. Вносятся предложения по совершенствованию текущего законодательства в сфере проведения комплексных кадастровых работ.

Ключевые слова и словосочетания: генеральное межевание, землепользование, Российская империя.

Б олее двадџати мет в России отмечается профессиональный праздник - Аень работников геодезии и картографии, установленный в соответствии с Указом Президента РФ от 11 ноября 2000 г. № 1867. История этого праздника связана с периодом правления Петра I. В марте 1720 г. Петр I подписал указ, который заложки начало картографическому деку в России. 
Указ устанавливац правика проведения сплошной съемки территории дмя создания подробной карты страны. С этого времени в России начались работы по массовому картографированию местности, появились такие спещиалисты, как межевщики и геодезисты, а впоследствии - и наука землеустройства в качестве отрасли научного знания.

С 2008 г., после вступления в силу Федерального закона от 24 июця 2007 г. № 221-Ф3 «О государственном кадастре неАвижимости» (в реА. от 1 января 2017 г.), в России сформировался институт кадастровых инженеров, «прародителями» которых по сути и явмяются «межевщики» петровских времен.

Межкевание, установление и определение границ землевладений явмяются основным звеном в сфере регулирования земельных отношений в масштабах страны. Эффективность государственного управления опредемяется прежде всего рациональным и сбалансированным подходом к использованию земли как природного ресурса. Аля выработки со стороны государства рациональных и взвешенных способов управления земельным фондом необходимо понимание размеров и пределов граниџ существующих территорий, установление и подАержание земельного правопорядка, что достигается путем проведения землеустроительных работ и межевания территорий.

История развития системы межевания земель берет свое начало еще в Аревней Руси. Первые упоминания о способах разграничения недвижимой собственности содержатся в Аревнейшем памятнике русского права - Русской Правде (1054 г.). В Пространной редакции Русской Правды устанавмиваются правила применения наказания в случае незаконного разграничения частной собственности на землю: «Если кто межу подрубит бортную или пашенную распашет или забором перегородит дворовую межу, то 12 гривен штрафа князю» [1, с. 109].

Аальнейшее законодательное закрепление порядка определенного порядка владения и пользования землей находит отражение в Псковской судной грамоте (XIV-XV вв.) - главном юридическом документе древнерусской республики. Статья 10 указанного документа содержит норму о необходимости проведения процедуры «перемера» землевладений в случае спорного дема [2, с. 321].

Судебник 1497 г. также содержкал ряд статей, регулировавших учет, обмер и описание землевладений. Первые чертежи, фиксирующие результаты проведения межевания земель, появияись к концу XV - началу XVI в. [3-5].

B XV1-XVII вв. появмяются первые книги по межеванию, возрастает его роль в связи с освоением новых земель, развитием городов, возврашением мюдей на «старые места», потерянные после монголо-татарского ига.

Следовательно, до начала XVIII в. в России не существовало единого установменного порядка проведения процедуры картографирования и межевания земель. Нормотворческая деятельность и реформы Петра I 
«создали» законодательную основу картографическому делу и дали толчок развитию и внедрению межкевания земель в России.

Масштаб петровских реформ в области проведения картографической съемки земель быц достаточно широкий, что оказало опредемяюшее воздействие как на развитие и становление земельного законодательства в Российской империи (1721-1917 гг.), так и на механизм правового регулирования земельных отношений в дореволюционной России. На протяжении всего периода существования Российской империи сложилось достаточно развитое земельное законодательство, прежде всего за счет появления институтов межевания и картографирования земель.

Аля успешной реализации реформ Петра I в сфере совершенствования картографии необходимы были высококвалифицированные кадры в области картографирования и межевания земель. С этой целью в России начали учрежкаться специальные учебные заведения. Московская школа цифири и землемерия (1698 г.), по словам А.Г. Анисимова, «...стала первой масточкой, создавшей весну русской геодезии» [4, с. 46].

В продолжение реформ Петра I законодательное закрепление межкевой деятельности и установление границ земельных наделов проводилось в период правления Ецизаветы I (1741-1762 гг.). К этому времени обстановка с регумированием частного землевладения в России становилась все более «запутанной», так как территория Российской империи расширялась, соответственно, увеличивалось число земель, а правовой механизм регулирования земельных отношений оставался прежним. В связи с этим 13 мая 1754 г. Елизавета I издает инструкцию дмя государственного межевания земемь («Инструкция межевщика»). ГАавной целью Аанного нормативного документа явмямось приведение в соответствие границ частных и казенных землевладений и одновременной фиксацией и выявлением прав на земемьные участки. Аля фиксации и сохранения полученных данных при межкевании согласно Инструкции составцялись такие необходимые документы, как полевая межевая записка, межевой журнал, межевая книга и межевые планы.

Предпосылкой для разработки и принятия Инструкщии послужило письмо государственного деятемя П.П. Шувалова в Сенат от 30 января 1752 г., в котором указывалось, что «непорядок в земельном кадастре приводит к многочисленным обидам и даже убийствам среди землевладельцев» [5, с. 6]. Предложение елизаветинского сановника сводимось к созданию документа Аця государственного межевания земель, и в качестве объекта для межевания по новым правикам для начала избиралась Московская губерния. Следует отметить, что названия документов, в которых согласно «Инструкции межевщика» полагалось вносить записи о результатах проделанных работ, имеют схожее название с современной документацией, предусмотренной и оформляемой в соответствии с требованиями Федерального закона от 13 января 2015 г. № 218-Ф3 «О государственном кадастре неАвижимости». 
Таким образом, в рассматриваемый исторический период в России были законодательно введены усовершенствованные нормы по учету земельных владений и внесению таких основных характеристик земельных участков, как местоположение граниџ, площадь, сведения о правообладателе. С утверждением в 1754 г. Инструкции амя государственного межевания земель связано появление в Российском государстве первых специализированных ведомств, в чьи функции входимо проведение межевых работ. Так, при Сенате была образована Гцавная межкевая канџелярия, а в Москве - губернская межевая канџемярии. Эти учреждения явмялись органами надзора за проведением непосредственно самих работ по обмеру землевладений (указанные функции были возложены на межевые конторы и межевые партии).

В «Инструкции межевщика» содержались нормы, устанавливающие ответственность и наказания (штраф 50 руб. или телесное наказание удары плетьми) дия тех миц, кто оказывал сопротивление межкевщикам в проведении работ по межеванию своего участка, включающих необходимые землеустроительные санкции. Законодателем подчеркивалась важность и значимость межевых работ дмя государства.

Необходимость в проведении работ по установлению граниџ землевлаАений, упорядочиванию сложившегося землепользования была необходимым инструментом как дця органов власти - в цемях принятия правицьных и эффективных решений государственного управления на уровне всей страны, так и для нормального течения повседневной жизни населения страны. Еще М.В. Аомоносов отмечал: «Немалый ущерб причиняется народу убийствами, кои бывают в Араках и от разбойников. Араки происходят вреАные межАу сосеАями и особливо межАу помещиками, которых ничем как межеванием, утушить не можно» [6, с. 399]. М.В. Аомоносов на собственном опыте испытал процедуру, связанную с установлением границ земельного участка. Известна история его спора с сосеАями по землеустройству в Санкт-Петербургской губернии. В 1761 г. российскому ученому пришлось обрашаться в ГАавную межевую канцемярию об отмежевании земель деревни Голубовицы, заселенных крестьянами, приписанными к его Усть-Рудиџкой фабрике, от земель генерала Скворџова.

Уже в начале правления Екатерины II стало очевидно, что работа межевых канџемярий не слишком эффективна, поэтому их функции были переданы Вотчиной коммегии, которая впоследствии стала главным органом по контролю за оборотом земли и по надзору за землепользованием в Российском империи.

Следующей важной вехой в системе управления земельным фондом страны стало направление в «земельной политике» Екатерины II, которое выразияась в проведении Генерального межевания земемь. Его начало было заложено обнародованием Манифеста от 19 сентября 1765 г. о генеральном размежевании земель всей империи, которое существенно отмичалось от межевания, проводимого Елизаветой II. Комплекс работ по межеванию 
1754 г. представцяц собой сплошное, валовое межевание, работы производились исключительно по инициативе государства, отказаться от проце-

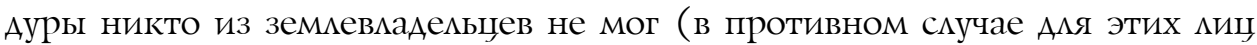
устанавливацись большие штрафы).

В основе Генерамьного межевания 1765 г. процедура обмера землевлаАений претерпела изменения: отменялась «юридическая составцяющая» процедуры межевания по Инструкции 1754 г., существенно тормозившая проведение межкевых работ, - проверка прав на землю. На законодательном уровне закреплялось положение о полюбовном разделе, «...то есть указаниям самими владельцами границ бесспорного вмадения» [7, с. 22] .

Однако, несмотря на всю важность и очевидность в необходимости упорядочивания сложившегося землепользования, в обществе начались волнения и споры, так как ранее (до проведения Генерального межкевания 1765 г.) землеустройство отличалось большей степенью неконтролируемости. В размещении земельных участков и их гранищ нереАки были случаи чересполосиџы частных владений (у одного собственника), вклинивания и вкрапливания земельных участков, что препятствовало рациональному и эффективному использованию земель, приводицо к земельным спорам. Чтобы снизить нарастающее недовольство населения, Екатерина II провозгласила межевой девиз: “Каждьй при сбоем» - и подтвердила его следующими знаменательными словами: «Уmbерди, Господи, достояние людям своим» [8]. Генеральное межевание охватимо 35 губерний России, в которых насчитывалось 188295 владений площадью 275378747 десятин земли.

В результате проведения Генерального межевания произошло усложнение сложившейся к концу XVII в. номенклатуры (деления) земель. Так, если ранее земельный фонд включал три категории земель - частновлаАельческие служилые, частновмадельческие церковные, земли дворџовые, то к началу XVIII в. земельный фонд включал следующие деление земель по категориям: земли частные, земли дворцовые и казенные, земли духовного ведомства; выгонные земли; земли заводов и фабрик; земли бывших низших разрядов служилых цюдей; земли военнослужащих; земли иноверцев; меса; дороги и бечевники.

Трудно переоценить значимость Генерального межевания 1765 г. Амя развития государства и управления страной. По мнению многих исследоватемей, в частности М.С. Рулева, «отечественной правовой наукой остается незаслуженно забытым период проведения Генерального межевания в Российской империи, а ведь именно после земельных реформ 1765 г. активизировался проџесс различного рода преобразований в данной правовой сфере» $[9$, с. 4] .

K концу XVIII в. результаты проведенных работ показали, что цель Генерального межевания 1765 г. - установление и закрепление на местности границ землевладений была достигнута. К началу XIX в. на повес- 
тку дня выносится новая задача: создание системы учета землевладений, системы земельного кадастра страны. Безусловно, благодаря проводимой Екатериной II политике в сфере землепользования, правовое регулирование земельных отношений было поднято на качественно новый уровень, что свидетельствовало о совершенствовании земельного законодательства и правоприменительной работе государственных органов, направленной на реализаџию принимаемых указов, инструкций и преАписаний в жизнь.

Историко-правовое исследование реформы Генерального межевания земель 1765 г. актуально и в настоящее время, прежде всего по причине преемственности в разрешении целого рада вопросов. По некоторым проблемным аспектам землепользования в Российской империи существовал более эффективный механизм и инструменты правового регулирования, чем в настоящее время.

Определенная связь прослежиивается между проводимыми работами по межкеванию 1754 г., Генеральным межеванием 1765 г. в Российской империи и институтом комплексных кадастровых работ в современной России, основной целью которых явмяется установцение граниџ территорий, землевладений в соответствии с их фактическим местоположением. Аействующим законодательством в сфере учетно-регистрационных проџедур и кадастровой деятельности регламентированы «комплексные кадастровые работы». Введено это понятие 1 января 2015 г. Федеральным законом от 24 июля 2007 г. № 221-Ф3 «О государственном кадастре недвижимости» (с 1 января 2017 г. - «О кадастровой деятельности»).

Введение данной процедуры свидетельствует об очевидном стремлении законодателя «навести порядок» в землепользовании современной России. Сегодня большая часть земельных участков, сведения о которых содержатся в государственном реестре неАвижимости, кибо не отмежевана - по причине отсутствия в реестре описания местоположения границ участков, мибо границы установлены и внесены в реестр с ошибками (так называемые реестровые ошибки). Все это усможняет гражданский оборот с земельными участками, затрудняет осуществление сделок с землей, а в некоторых случаях приводит и к судебным разбирательствам.

Аействующее законодательство содержкит норму о запрете регистраџии перехода права по сделкам с земельными участками, граниџы которых не установцены, мибо имеется наложение границ на смежные (соседние) земельные участки ввиду наличия реестровой ошибки. Аیя исправления ситуации правообладателям приходится самостоятельно исправцять допущенные ранее ошибки при межевании, возникшие не по их вине, а сама административная проџедура, как правило, занимает продолжительное время и требует финансовых затрат со стороны собственников земельных участков на выполнение кадастровых работ.

Решить подобные проблемы на законодательном уровне предкагается с использованием правового инструмента комплексных кадастровых ра- 
бот, которые преАставцяют собой проведение мероприятий по уточнению местоположения граниџ существующих земельных участков; обеспечение исправления реестровых ошибок в сведениях о местоположении границ; правовое закрепление образования земельных участков общего пользования. Проводить комплексные кадастровые работы в отношении опредеменной территории (чаще всего - кадастровый квартал) следует за счет государственных среАств.

Очевидно, что цель введения процедуры комплексных кадастровых работ - повышение эффективности управления территориями и земемьным фондом России. Результаты, полученные в ходе проведения указанных работ, позволят пополнить реестр недвижимости новыми сведениями об объектах неАвижимости и повысить «качество» внесенной в офиџиальный государственный реестр информации.

Проблемы, которые «тормозят» проведение комплексных кадастровых работ и тем самым препятствуют их эффективному правоприменению, обсуждались на «круглом столе» Комитета Совета Федерации по экономической политике 3 декабря 2020 г. [10]. Среди них выдемены основные: отсутствие необходимой градостроительной документации (проектов межевания) и необходимость внесения изменений в бюджеты местного уровня дця планирования финансовых среАств при проведении данного вида работ. В сфере учетно-регистрационных действий законодателем не регламентирована процедура постановки на государственный кадастровый учет выявленных объектов без согласия правообладателей. Со стороны российских регионов поступают настойчивые предложения о сокращении сроков рассмотрения в государственных регистрирующих органах документации, подготовленной в результате выполнения комплексных кадастровых работ.

На основе проведенного анализа и сложившейся практики в сфере каАастровых отношений можно сделать вывод о недостаточной эффективности существующего механизма проведения комплексных кадастровых работ.

В целях совершенствования законодательства в учетно-регистрационной и кадастровой сферах предлагается пересмотреть существующие нормы, регулирующие область комплексных кадастровых работ в части сокращения сроков рассмотрения документации, регламентации процеАур учета объектов недвижимости в рамках выполнения указанных работ, а также определить источники финансирования и субсидирования органов местного самоуправления на осуществление комплексных кадастровых работ.

\section{Библиографический список}

1. Библиотека литературы Древней Руси: в 15 т. Т. 4: XII век / под ред. Д.С. Лихачева, Л.А. Дмитриева, А.А. Алексеева, Н.В. Понырко. СПб., 1997. 
2. Псковская судная грамота // Российское законодательство X-XX вв.: в 9 т. Т. I: Законодательство Древней Руси. М., 1984.

3. Кусков В.С. Картографическое искусство Русского государства. М., 1989.

4. Анисимов А.Г., Гришаев С.В., Медведь А.Н., Покровская С.В. История землеустройства и инвентаризации в России. М., 2009.

5. Бухерт В.Г. Ради пресечения доныне в спорах и в завладении земель происходящих убивств: Земельный вопрос в России // Родина: журнал. Приложение: Документы русской истории: 2003. № 2 (62).

6. Ломоносов М.В. О сохранении и размножении российского народа // Полное собрание сочинений: в 11 т. Т. 6: Труды по русской истории, общественно-экономическим вопросам и географии. М.; Л., 1952.

7. Савенко Г.В., Ялбулганов А.А. Земельные участки: образование, межевание и земельные иски (вторая половина XVIII - начало XXI в.). М., 2017.

8. Манифест о Генеральном размежевании земель в империи во всей империи с приложением генеральных правил, данных Межевой комиссии и высочайше утвержденного реестра о ценах на продажу земель в губерниях и провинциях» от 19 сент. 1765 г. URL: https://elib.rgo.ru/handle/123456789/218879

9. Рулев М.С. Органы межевания и разрешение межевых споров в Российской империи: историко-правовое исследование: автореф. дис. ... канд. юрид. наук. М., 2019.

10. В Совфеде назвали основные проблемы при комплексных кадастровых работах / Д.В. Гончарук // Парламентская газета. 2020. 3 дек. URL: https://www.pnp.ru/social/v-sovfedenazvali-osnovnye-problemy-pri-kompleksnykh-kadastrovykh-rabotakh.html 